\title{
CARACTERIZAÇÃO E PERSPECTIVAS DO POLO MOVELEIRO DE CORONEL FREITAS, SC, BRASIL
}

\author{
Beno Nicolau Bieger ${ }^{1}$, Luiz Roberto Graça ${ }^{2}$, Vitor Afonso Hoeflich ${ }^{3}$, Anadalvo Juazeiro dos Santos ${ }^{4}$ \\ Romano Timofeiczyk Júnior ${ }^{4}$ \\ ${ }^{1}$ Eng. Florestal, Dr., Universidade Comunitária Regional de Chapecó, Chapecó, SC, Brasil - benonicolau @ gmail.com \\ ${ }^{2}$ Eng. Agrônomo, Dr., Embrapa Florestas, Colombo, PR, Brasil - lrgraca@gmail.com \\ ${ }^{3}$ Eng. Agrônomo, Dr., Depto. de Economia Rural e Extensão, UFPR, Curitiba, PR, Brasil - hoeflich@ufpr.br \\ ${ }^{4}$ Eng. Florestal, Dr., Depto. de Economia Rural e Extensão, UFPR, Curitiba, PR, Brasil - ajsantos@ufpr.br - romano@ufpr.br \\ Recebido para publicação: 04/06/2008 - Aceito para publicação: 15/08/2008
}

\begin{abstract}
Resumo
Pesquisou-se, no período 2005-2007, o perfil das indústrias moveleiras dos municípios de Chapecó e Coronel Freitas, no oeste de Santa Catarina, com o objetivo de conhecer, analisar, caracterizar e indicar as perspectivas de sustentabilidade da atividade moveleira nesses municípios. Para tanto, efetuou-se um censo completo, aplicando-se questionário com respostas abertas e fechadas, bem como visita às linhas de produção das indústrias. Em Coronel Freitas, são dezoito firmas razoavelmente estruturadas, produzindo cozinhas, salas de jantar, balcões para banheiro e dormitórios. Em Chapecó, restam dez fabricando móveis em série e mais vinte e nove fabricando móveis sob medida. O mercado apresentou-se imperfeitamente competitivo, com nuanças de diferenciação de produtos e na busca de nichos de mercado que lembram características de concentração. O nível tecnológico vai do artesanal à mais moderna tecnologia com linha totalmente automatizada. As empresas tiveram um faturamento anual de $\mathrm{R} \$ 49.389 .000,00$, mas têm um potencial de até R\$ 92.631.000,00. Pela classificação da "Lei do Simples", 40\% são microempresas e $46 \%$ são empresas de pequeno porte. As principais dificuldades alegadas são os impostos, a legislação trabalhista, a falta de mão-de-obra qualificada, a falta de política governamental, o mercado consumidor e o capital de giro. O estudo permitiu sugerir diversas políticas governamentais (federal, estadual e municipal) visando à sustentabilidade econômica, bem como ações entre as próprias empresas, especialmente no sentido da celebração de parcerias.
\end{abstract}

Palavras-chave: Produtos florestais; análise econômica; cadeia produtiva; sustentabilidade; madeira.

\begin{abstract}
Characterization and perspectives of the wood furniture industry of Coronel Freitas, SC, Brazil. The present research is a study curried out from 2005-2007 on the profile of furniture industries in the municipalities of Chapecó and Coronel Freitas, located in the western region of the State of Santa Catarina, Brazil. The main objectives were to characterize and to analyze the productive/supply chain in order to learn about the perspectives of sustainability of the furniture industry. For that purpose, a complete census applying a questionnaire with open and closed answers was made, as well as visit to the production lines of the industries. In Coronel Freitas there were eighteen reasonably structured companies, producing kitchens, dining rooms, bathroom and bedroom counters. In Chapecó only ten companies were left making standardized furniture and twenty nine making customized furniture. The market has presented some imperfect competition nuances, with product differentiation and the search for new niches. Most firms (46\%) are of small size while $40 \%$ are even smaller, the so-called microenterprises. The technological level varied from the simple artisan up to full mechanization. Gross average annual revenue was estimated to be around $\mathrm{R} \$ 49.389,000.00$ with a potential to reach $\mathrm{R} \$$ 92.631,000.00. The main reasons alleged for the actual situation were: taxes, labor legislation, labor training, lack of official policies, market demand and cash flow problems. The study allowed us to infer and to suggest several government policies, at three levels, in order for economic sustainability and also actions among the enterprises in particular those stimulating partnerships.
\end{abstract}

Keywords: Forest products; economic analysis; productive chain; sustainability; wood. 


\section{INTRODUÇÃO}

A estrutura da indústria moveleira no Brasil, de acordo com os dados da ABIMÓVEL ${ }^{1}$ aponta para 16.104 estabelecimentos empregando 206.352 pessoas em 2006. Estima-se, no entanto, a existência de mais de 50.000 unidades produtoras de móveis. Garrido (2004) afirma existirem 16.000 empresas (micro, pequenas e médias) gerando em torno de 190.000 empregos diretos, ressaltando também para a elevada existência da informalidade, que aumentaria em muito esses números. Os dados da Associação Brasileira da Indústria de Madeira Processada Mecanicamente (ABIMCI) apontam que a indústria de Base Florestal gera um PIB de US\$37,3 bilhões em 2005 (3,5\% do PIB nacional).

O BNDES (Banco Nacional de Desenvolvimento Econômico e Social) vem atuando fortemente no segmento de indústrias de móveis, tanto na expansão como no desenvolvimento tecnológico, tendo destinado a cifra de US $\$ 838,7$ milhões no período de 1998 a $2007^{2}$. Aproximadamente $60 \%$ desse montante vêm sendo destinado às micro e pequenas empresas.

As exportações brasileiras de móveis vêm sendo impulsionadas pela competitividade dos produtos brasileiro, principalmente os que utilizam madeira certificada. Quanto "à participação do Brasil no mercado mundial de móveis, o país é o $10^{\circ}$ maior produtor, o $10^{\circ}$ maior consumidor, o $24^{\circ}$ maior exportador e o $35^{\circ}$ maior importador" (ABIMÓVEL, 2003).

A maior parte das unidades industriais de móveis de madeira localiza-se na região centro-sul, respondendo por $90 \%$ da produção nacional e $70 \%$ da mão-de-obra demandada no setor. A indústria moveleira já estabelecida em Santa Catarina tem o maior centro exportador do país localizado no polo moveleiro de São Bento do Sul. Sua produção é basicamente de móveis residenciais de madeira de pinus (80\%), participando com 40\% do volume nacional exportado (ABIMÓVEL, 2003). Em 2003, sua participação passou a ser de 50\% (ABIMÓVEL, 2004).

No estado de Santa Catarina há diversos polos moveleiros consolidados. O SEBRAE classifica a atividade moveleira do oeste de Santa Catarina como APL (Arranjo Produtivo Local) de móveis do oeste de SC. A AMEOSC e SIMOVALE preferem falar em Polo Moveleiro do Oeste Catarinense. A área (geográfica) de interesse deste estudo é o Polo Moveleiro de Coronel Freitas (classificação BNDES), que envolve os municípios de Chapecó e Coronel Freitas, pertencentes à AMOSC.

Alguns dos empreendimentos neles localizados continuam modestos e se situam em um patamar com poucas perspectivas reais de desenvolvimento. Problemas tecnológicos e/ou de gestão têm contribuído para que esses empreendimentos ainda permaneçam no empirismo. Muitos deles, no entanto, vêm saindo ou já saíram da informalidade e se transformaram em indústrias com importante potencial produtivo.

O presente estudo pretende caracterizar e dimensionar a importância econômica, social e algumas interfaces ambientais da atividade moveleira nos municípios de Chapecó e Coronel Freitas, indicando alternativas de práticas sustentáveis de longo prazo.

Os objetivos específicos foram: classificar e quantificar as indústrias e produtos da cadeia produtiva existente na região; identificar os principais fornecedores de matérias-primas, especialmente insumos e produtos de origem florestal; identificar e classificar os principais mercados atendidos pelos produtores/indústrias abordados; analisar as principais dificuldades organizacionais quanto ao aspecto econômico institucional; estudar o grau de tecnologia da indústria e identificar os resíduos produzidos bem como o destino dado a eles; estudar a estrutura do mercado, sua concentração e suas relações; e, finalmente, propor e sugerir políticas que viabilizem a sustentabilidade econômica e social da atividade moveleira na região estudada no longo prazo.

\section{MATERIAL E MÉTODOS}

O presente estudo foi realizado nas empresas cadastradas nas prefeituras municipais de Chapecó e Coronel Freitas, bem como nos estabelecimentos não cadastrados, mas que foram indicados pelos fornecedores de matérias-primas (madeira e chapas) ou encontrados na varredura feita nos dois municípios, com atividades relacionadas ao setor moveleiro localizadas na região abrangida pela

\footnotetext{
${ }^{1}$ http://www.abimovel.org.br/?pg=panorama_setor. Acesso em: 27 fev. 2008.

${ }^{2}$ Disponível em: <http://www.bndes.gov.br/estatisticas/download/Int2\%201D\%20a\%20setorCNAE.pdf.> Acesso em 05 maio 2008.
} 
pesquisa. Assim sendo, foram pesquisados todos os estabelecimentos com endereço fixo, máquinas e equipamentos instalados e em atividade. Os estabelecimentos encontrados fechados foram visitados diversas vezes em horários diferentes para confirmar a atividade ou não. Foram excluídos os artesãos e os "marceneiros de fim de semana". A pesquisa completa, sob a forma de censo, foi realizada no período de 2005 a 2007.

\section{Instrumentos de coleta e tratamento dos dados}

Os instrumentos de coleta dos dados utilizados foram:

a) Pesquisa bibliográfica, porque no anteparo teórico para a fundamentação do tema realiza-se investigação em material publicado e indexado em base de dados, de cunho científico, como revistas especializadas, livros, artigos, dissertações, teses, trabalhos apresentados em congressos e disponíveis na rede mundial de computadores (Internet).

b) Pesquisa documental realizada nos demonstrativos de produção e materiais, de vendas e outros relatórios oriundos das empresas pesquisadas, que foram objeto de publicação ou não, além de documentos de associações, entidades privadas e governamentais ligadas ao objeto de estudo.

c) Observação: foram efetuados levantamentos in loco dos métodos produtivos e tecnológicos, além das rotinas utilizadas nas linhas de produção, nas organizações em estudo.

d) Questionário: foi elaborado e aplicado um questionário com perguntas abertas e fechadas objetivando a identificação do perfil das empresas em estudo, bem como a confecção de um banco de dados necessário para melhor caracterizar a atividade. O modelo do questionário pode ser visto em Bieger (2008).

\section{Análise e interpretação dos dados}

Os dados quantitativos foram criteriosamente analisados com agrupamento de respostas similares por meio de análises descritivas, apresentadas e ilustradas em tabelas e figuras, efetuando-se diversos cruzamentos de variáveis. Os dados qualitativos receberam análise interpretativa.

A análise econômica foi feita de acordo com conceitos desenvolvidos por diversos autores. A avaliação do desempenho econômico de um setor tem revelado uma missão bastante complexa. As interrelações comerciais, os interesses paralelos, os incentivos ou restrições de ordem oficial, as estruturas do macromercado existente, entre outras, são variáveis que direta ou indiretamente exercem poder e influenciam o desempenho e seu desenvolvimento. Apesar disso, algumas análises são pertinentes e possibilitam diversas avaliações mesmo que parciais.

As tabelas agrupam as empresas do polo moveleiro em segmentos chamados "sob medida" e "seriados", confrontam as empresas entre os dois municípios e ainda a classificação por faixa de faturamento, quais sejam: microempresa (faturamento anual até $\mathrm{R} \$ 240.000,00$ ), empresa de pequeno porte (faturamento anual de $\mathrm{R} \$ 240.000,00$ a $\mathrm{R} \$ 2.400 .000,00$ ) e empresas com faturamento anual acima de $\mathrm{R} \$ 2.400 .000,00$.

A produtividade foi analisada comparando-se as variáveis faturamento e mão-de-obra. Um índice gerado pelo quociente faturamento $\mathrm{X}$ investimento em cada segmento também foi analisado.

Para analisar a estrutura e a concentração do mercado, fez-se uma análise por diversos métodos. Rocha, Bueno e Pires (2004), citando Hall; Tideman (1987) ${ }^{3}$, e Hannah; Kay (1977) ${ }^{4}$ listam diversos índices apropriados para os estudos de estrutura e concentração de mercado. Os mais largamente utilizados são a TCM (Taxa de Concentração do Mercado) e o IHH (Índice de Herfindahl-Hirschman).

A $\mathrm{TCM}^{5}$, classificada como um índice parcial, é a taxa de concentração do mercado e representa a relação percentual do faturamento, empregados, ativos, valor adicionado ou produção das quatro ou oito maiores empresas e o faturamento ou variável analisada do setor. Para apresentar os resultados em forma de tabelas, foram calculadas as TCM para as diversas classificações estudadas, considerando o faturamento dos quatro maiores produtores em cada segmento. Para se analisar a participação de cada indústria nos respectivos mercados analisados, se for considerado $\mathbf{Q}$ o valor do faturamento total e $\mathrm{q}_{\mathrm{i}} \mathrm{O}$

\footnotetext{
${ }^{3}$ Hall, M.; Tideman, N. Measures of Concentration. Journal of the American Statistical Association, 62(317), 162-168, 1987.

${ }^{4}$ Hannah, L.; Kay, J. Concentration in Modern Industry. Macmillan, London, 1977.

${ }^{5} \mathrm{TCM} \cong 100 \%$ - segmento altamente concentrado; TCM $\cong 0 \%$ - segmento de baixa concentração; TCM < $40 \%$ - mercado concorrencial (competitivo); TCM $>60 \%$ - setor mais concentrado.
} 
faturamento de cada indústria, tem-se que o somatório de $\mathrm{q}_{\mathrm{i}}$ é igual a $\mathbf{Q}$. Ou seja, de acordo com Barbosa (1985) e Santos (2000), citando Ferguson; Ferguson (1994) $)^{6}$, e Shy $(1996)^{7}$, tem-se a seguinte expressão:

$$
Q=\sum_{i=1}^{n} q_{i}
$$

O Market Share (MS) mede a parcela de cada empresa do valor total da variável analisada. O Índice de Herfindahl-Hirschman (IHH) ${ }^{8}$ é um índice que eleva ao quadrado o MS, com o intuito de elevar o peso das maiores empresas dentro do mercado analisado. De acordo com os mesmos autores citados anteriormente, esse índice é dado pela seguinte expressão:

$$
I H H=\sum_{i=1}^{n} M S_{i}^{2} \quad \text { em que } \quad M S=\frac{q_{i}^{*} 100}{Q}
$$

Esse índice também está discriminado em forma de tabela, calculando os índices para cada classificação abordada, bem como para o mercado como um todo.

Caves (1982) estabeleceu uma classificação própria para estruturas de mercado, levando em consideração a produção. Essa classificação pode ser vista na tabela 1.

Tabela 1. Classificação de estruturas de mercado segundo Caves (1982).

\begin{tabular}{|c|c|c|c|}
\hline \multirow{2}{*}{ Estrutura de mercado } & \multicolumn{3}{|c|}{ Participação na produção total } \\
\hline & 4 maiores & 8 maiores & 20 maiores \\
\hline Oligopólio I & & $50 \%$ & $75 \%$ \\
\hline Oligopólio II & & $33 \%$ & $75 \%$ \\
\hline Indústria não concentrada & & $<33 \%$ & \\
\hline Indústria competitiva & $<10 \%$ & & \\
\hline
\end{tabular}

Table 1. Market structure according to Caves (1982).

Portanto, o critério adotado estabelece:

Oligopólio tipo I - as 8 maiores firmas produzem pelo menos 50\% da produção, sendo que as 20 maiores contribuem com um mínimo de $75 \%$ do total e nenhuma firma sozinha oferta mais do que $10-15 \%$;

Oligopólio tipo II - as 8 maiores firmas fazem pelo menos $33 \%$ da produção e as 20 maiores um mínimo de $75 \%$;

Indústrias não concentradas - as 8 maiores firmas fazem menos que $33 \%$ da produção;

Indústria competitiva - as 4 maiores empresas produzem menos que $10 \%$ do total vendido.

Aplicando esses conceitos para a situação pesquisada e utilizando a variável "faturamento", são apresentados, em forma de tabela, os percentuais dessa variável, em cada segmento do polo moveleiro.

\section{RESULTADOS E DISCUSSÃO}

O presente trabalho deteve-se nos elos Insumos, Processamento e Indústria, Comercialização (atacadista e varejista) e Consumidor da descrição de cadeias produtivas. Deu-se especial atenção à postura empresarial diante dos problemas e limitações apontados, bem como às alternativas de sustentabilidade imaginadas pelos atores envolvidos. Pelas características identificadas, procedeu-se à análise com as classificações de localização geográfica, confrontando Coronel Freitas X Chapecó, bem como a classificação entre produtores de móveis sob medida $\mathrm{X}$ produtores de móveis em série.

\footnotetext{
${ }^{6}$ FERGUSON, P.R., FERGUSON, G.J. Industrial Economics: issue and perspectives. New York: University Press, 1994.

${ }^{7}$ SHY, O. Industrial organization: theory and applications. London: The MIT Press, 1996.

${ }^{8} \mathrm{Se}$ IHH $>1.800$, o mercado é concentrado.

Se IHH <1.800, o mercado é de alta competição.

Se $\mathrm{IHH}=10.000 \rightarrow$ o mercado é altamente concentrado (monopólio).

Se IHH $=0 \rightarrow$ concorrência perfeita.
} 
A figura 1 mostra o fluxograma dos segmentos que formam a cadeia de produção de móveis de Coronel Freitas e Chapecó e as relações que estabelecem ao longo da cadeia.

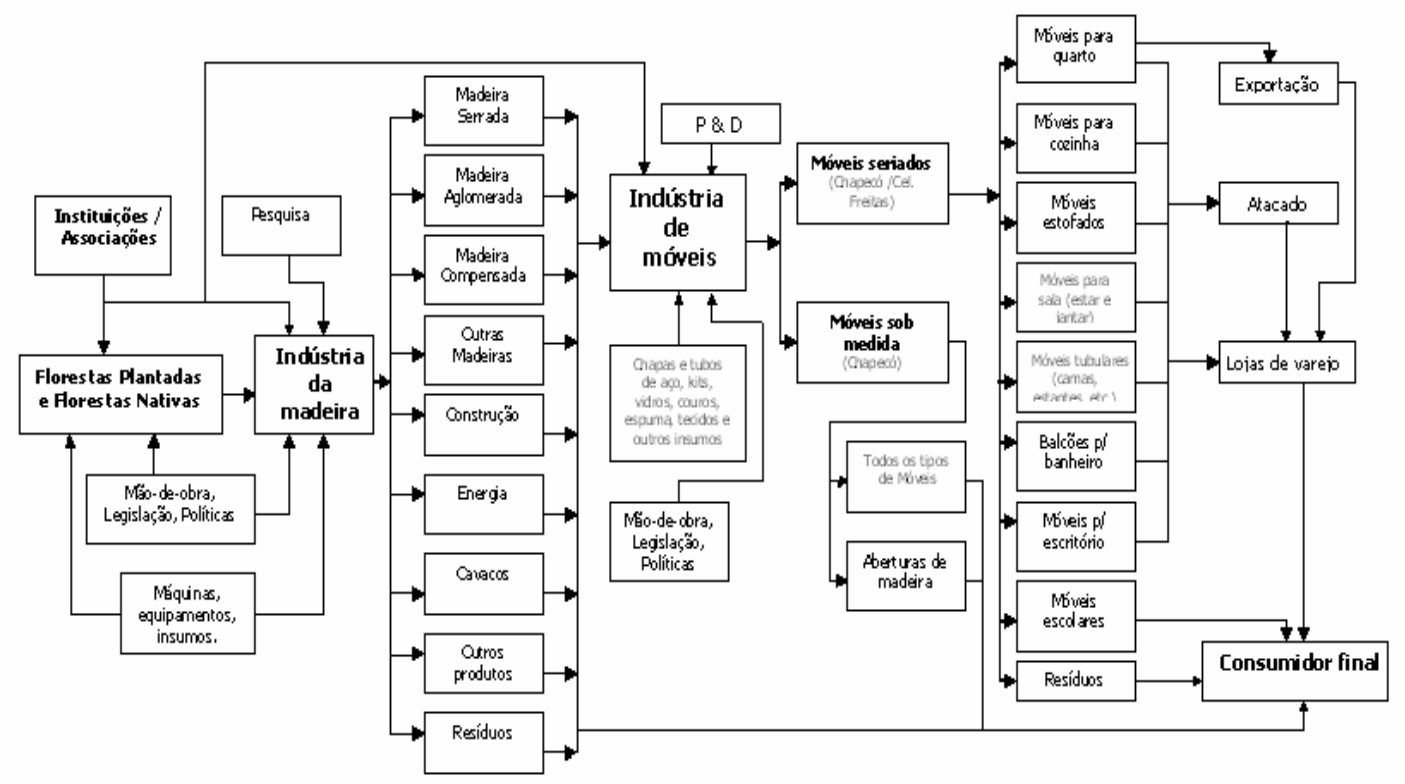

Figura 1. Subsistema Indústria Moveleira do Polo Moveleiro de Coronel Freitas.

Figure 1. Subsystem of wood furniture industries from the Coronel Freitas pole.

Fonte: Bieger (2008) (adaptado).

\section{Fornecedores de matéria prima florestal para as indústrias de móveis do polo moveleiro de Coronel Freitas}

Na identificação e catalogação dos principais fornecedores de matéria-prima florestal para o polo moveleiro de Coronel Freitas, foi constatado que o eucalipto consumido pelas indústrias é produzido na região, sendo fruto do trabalho de fomento desenvolvido nas últimas décadas pelas agroindústrias locais (Sadia, Frigorífico Chapecó e CooperAlfa). Já o pinus vem da região das indústrias de papel e celulose (Meio Oeste e Planalto Catarinense), com exceção da Sadia Concórdia, que planta pinus para a confecção das embalagens de seus produtos e tem excedente produtivo que é vendido para as serrarias e indústrias da região. O preço do eucalipto é bastante homogêneo, sendo que a variação se deve à qualidade - de primeira ou de segunda - que é demandada pelo produto fabricado. Uma das empresas de Chapecó está até mesmo começando a usar essa madeira em substituição ao mogno. Está aí uma importante oportunidade para desenvolver pesquisa tecnológica nesse sentido, tanto no Centro Moveleiro do SENAI como na Universidade.

Outra espécie utilizada e com grande potencial é o kiri ${ }^{9}$. O empresário que a está utilizando afirma ser essa madeira muito melhor do que a caixeta, espécie que vem para Chapecó oriunda principalmente da região de Ariquemes/RO e do sul do Pará. A vantagem do kiri é o impecável acabamento que proporciona, diz o empresário.

Em termos de madeira nativa, foi identificado um grande número de fornecedores. As madeireiras da região são, em sua maior parte, entrepostos ou depósitos de madeira comprada do Norte e Centro-Oeste do país, especialmente do Mato Grosso, do Pará e de Rondônia. Essa madeira é trazida por caminhoneiros que aproveitam suas viagens àquela região para trazer a madeira como frete de retorno, otimizando sua atividade. A região oeste praticamente não tem mais reservas florestais nativas para serem exploradas. Corrobora essa situação a legislação florestal restritiva quanto à exploração florestal nas áreas remanescentes.

\footnotetext{
${ }^{9}$ Paulownia spp., gênero arbóreo da família Scrophulariaceae, originário do leste da Ásia.
} 
A variação de preço da madeira nativa é muito grande em função do tipo de madeira utilizada por cada indústria. Este fato ocorre porque algumas utilizam madeira de primeira ${ }^{10}$ para a fabricação de móveis sob medida para as classes $\mathrm{A}$ e $\mathrm{B}^{11}$, enquanto que outras utilizam madeira de segunda ou até mesmo aproveitamento e refilo de acordo com a destinação que lhe é dada, como, por exemplo, partes da estrutura interna de estofados. As espécies utilizadas têm grande diversidade, tendo quase sempre a disponibilidade de espécie substituta para aquela demandada.

As empresas de móveis também dispõem de um grande número de fornecedores de madeira laminada, compensada e aglomerada. Enquanto as grandes empresas compram esse material na forma de palets para conseguir um diferencial de preços, as pequenas empresas compram em chapas unitárias, de acordo com a demanda, enquadrando-se, por necessidade, no conceito just-in-time ${ }^{12}$. As chapas demandadas têm diversas espessuras, sendo as especificações definidas de acordo com o produto que está sendo fabricado. Da mesma forma, os preços praticados dependem, além das especificações dessa matéria-prima, das quantidades adquiridas, da forma de pagamento e da vinculação dessa compra a outros itens, como por exemplo a aquisição de kits de ferragens.

\section{Área industrial instalada e potencial}

A pesquisa realizada apurou uma área total instalada/construída de $65.456,00 \mathrm{~m}^{2}$. Neste levantamento, consta a soma das áreas dos pavilhões/galpões industriais efetivamente utilizados na confecção de seus produtos. Considerando a realidade desse polo e, para efeito didático, optou-se em classificar essas indústrias em duas classes distintas, de acordo com a característica do produto: móveis sob medida e móveis em série. Assim sendo, foram pesquisadas trinta e nove empresas em Chapecó, sendo que vinte e nove fabricam móveis sob medida (50\% do total) e dez (18\% do total) produzem seriados, e dezoito empresas em Coronel Freitas, todas fabricando móveis em série (32\% do total).

Ainda com a mesma classificação, buscou-se estabelecer o valor de cada unidade produtiva. $\mathrm{Na}$ tabela 2, comparam-se os valores de mercado que cada empresário dá a seu negócio, apresentando as totalizações. Esses valores consideram o terreno, as construções, as máquinas e a marca. Essa percepção ou valoração apura um total de $\mathrm{R} \$ 54.358 .000,00$.

Tabela 2. Área construída total $\mathrm{em}^{2}$ e valor total em $\mathrm{R} \$$ do negócio para as empresas do polo moveleiro de Coronel Freitas por segmento - 2007.

Table 2. Buldings total area in $\mathrm{m}^{2}$ and total value in $\mathrm{R} \$$ for the companies of the pole of Coronel Freitas by segment -2007 .

\begin{tabular}{lcccccc}
\hline & \multicolumn{2}{c}{ Chapecó } & \multicolumn{2}{c}{ Coronel Freitas } & \multicolumn{2}{c}{ Totais polo } \\
\cline { 2 - 7 } & $\begin{array}{c}\text { Área } \\
\text { construída } \\
\left(\mathbf{m}^{2}\right)\end{array}$ & $\begin{array}{c}\text { Valor } \\
(\mathbf{R} \mathbf{})\end{array}$ & $\begin{array}{c}\text { Área } \\
\mathbf{c o n s t r u i ́ d a} \\
\left(\mathbf{m}^{2}\right)\end{array}$ & $\begin{array}{c}\text { Valor } \\
(\mathbf{R} \mathbf{\$})\end{array}$ & $\begin{array}{c}\text { Área } \\
\mathbf{c o n s t r u i ́ d a} \\
\left(\mathbf{m}^{2}\right)\end{array}$ & $\begin{array}{c}\text { Valor } \\
(\mathbf{R} \mathbf{)})\end{array}$ \\
\hline Móveis sob medida & $12.341,00$ & $11.070 .000,00$ & - & - & $12.341,00$ & $11.070 .000,00$ \\
Móveis em série & $18.975,00$ & $25.428 .000,00$ & $34.140,00$ & $17.860 .000,00$ & $53.115,00$ & $43.288 .000,00$ \\
\hline Total & $31.316,00$ & $36.498 .000,00$ & $34.140,00$ & $17.860 .000,00$ & $65.456,00$ & $54.358 .000,00$ \\
\hline
\end{tabular}

Fonte: Bieger (2008).

A área média das empresas que fabricam móveis sob medida é de 425,55 $\mathrm{m}^{2}$, contra aproximadamente 1.895,00 $\mathrm{m}^{2}$ das seriadas, tanto em Chapecó como em Coronel Freitas. As empresas que se organizam para produzir em série constroem fábricas maiores, padronizadas, quase todas em galpões de concreto pré-moldado.

Da tabela 2 se pode ainda deduzir que a média do valor por área corresponde a $\mathrm{R} \$ 830,45$ por metro quadrado. No entanto, as indústrias localizadas em Chapecó têm um valor significativamente maior que as de Coronel Freitas. As que trabalham com móveis sob medida têm um valor de R $\$ 897,01 / \mathrm{m}^{2}$ contra $\mathrm{R} \$ 1.340,08 / \mathrm{m}^{2}$ nas seriadas e contra apenas $\mathrm{R} \$ 523,14 / \mathrm{m}^{2}$ para as de Coronel Freitas (que trabalham todas com móveis em série). Essa diferença pode ser explicada por ser Chapecó o polo

\footnotetext{
${ }^{10}$ A madeira é classificada como sendo "de primeira" quando está isenta de defeitos e cortada em dimensões padronizadas.

${ }^{11}$ Classes A e B - são consideradas as famílias com alto poder aquisitivo.

12 Just-in-time - conceito de gestão de estoques que preconiza a compra ou especialmente a entrega de produtos diretamente (na linha de montagem) no momento em que serão utilizados na fabricação.
} 
econômico e geográfico do oeste de Santa Catarina, pelo valor dos imóveis ser significativamente maior, bem como pelo padrão tecnológico maior de diversas empresas seriadas de Chapecó, elevando a sua média.

Em Coronel Freitas, a maioria das indústrias foi construída com projetos similares: galpões prémoldados em áreas industriais na periferia da cidade. Já em Chapecó apenas uma empresa está nesse momento se instalando em área industrial subsidiada pelo poder público. Essa situação também gerou uma outra característica: em Coronel Freitas não há mais empresas pequenas para fabricação de móveis sob medida; todas se transformaram em fabricantes de móveis em série, fruto de um longo trabalho do SEBRAE realizado nos últimos anos. O resultado desse trabalho é agora colocado em xeque por alguns, que venderam todo o patrimônio amealhado por décadas com a fabricação de móveis sob medida, para investir no atual negócio "moderno", que se transformou, em alguns casos, em dívidas impagáveis junto às instituições financeiras. $\mathrm{O}$ que se deve analisar e avaliar é, na verdade, a competência gerencial de muitos dos atores envolvidos.

Por outro lado, em Chapecó as indústrias foram ampliando suas instalações em imóveis próprios ou alugados. Para elas há inclusive uma ideia clara de que a ampliação pode se dar com a expansão do próprio negócio, com a construção ou adaptação de loja ou show room, ou até mesmo o investimento em outros negócios completamente diferentes do atual.

\section{Faturamento}

Esse quesito levantado buscou a informação do movimento financeiro gerado pela organização. O empresário foi estimulado a informar o volume real de dinheiro gerado por seu negócio, independentemente de ter havido o faturamento real. A soma desses valores aponta para um faturamento total de $\mathrm{R} \$ 22.524 .000,00$ em Chapecó (somando fabricantes de móveis seriados e sob medida) e mais $\mathrm{R} \$$ 26.865.00,00 em Coronel Freitas (Tabela 3).

Tabela 3. Faturamento real $\mathrm{X}$ potencial $\mathrm{X}$ ociosidade em $\mathrm{R} \$$ nas categorias de móveis sob medida $\mathrm{e}$ móveis em série - 2007.

Table 3. Potential real invoicing $\mathrm{X}$ idleness in $\mathrm{R} \$$ in the categories of furniture custom made and furniture serially made - 2007.

\begin{tabular}{|c|c|c|c|c|}
\hline & \multicolumn{4}{|c|}{ Chapecó } \\
\hline & Faturamento anual & Potencial & "Ociosidade" & Percentual \\
\hline Móveis sob medida & $5.654 .000,00$ & $12.291 .000,00$ & $(6.637 .000,00)$ & $117,39 \%$ \\
\hline Móveis em série & $16.870 .000,00$ & $21.730 .000,00$ & $(4.860 .000,00)$ & $28,81 \%$ \\
\hline \multirow{3}{*}{ Total (anual) } & $22.524 .000,00$ & $34.021 .000,00$ & $(11.497 .000,00)$ & $51,04 \%$ \\
\hline & \multicolumn{4}{|c|}{ Coronel Freitas } \\
\hline & Faturamento anual & Potencial & "Ociosidade" & Percentual \\
\hline Móveis sob medida & 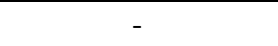 & - & & - \\
\hline Móveis em série & $26.865 .000,00$ & $58.610 .000,00$ & $(31.745 .000,00)$ & $118,16 \%$ \\
\hline \multirow[t]{3}{*}{ Total (anual) } & $26.865 .000,00$ & $58.610 .000,00$ & $(31.745 .000,00)$ & $118,16 \%$ \\
\hline & \multicolumn{4}{|c|}{ Totais } \\
\hline & Faturamento anual & Potencial & "Ociosidade" & Percentual \\
\hline Móveis sob medida & $5.654 .000,00$ & $12.291 .000,00$ & $(6.637 .000,00)$ & $117,39 \%$ \\
\hline Móveis em série & $43.735 .000,00$ & $80.340 .000,00$ & $(36.605 .000,00)$ & $83,70 \%$ \\
\hline Total (anual) & 49.389.000,00 & $92.631 .000,00$ & $(43.242 .000,00)$ & $87,55 \%$ \\
\hline
\end{tabular}
Fonte: Bieger (2008).

Concomitante a essa situação, também houve o estímulo para projeção do faturamento, levando em consideração as instalações atuais (capacidade instalada) em um ambiente/cenário de negócios altamente favorável. Totalizando os valores projetados, há uma expectativa de que, em um cenário favorável, haveria um incremento de geração de riqueza de $\mathrm{R} \$ 43.242 .000,00$ anuais. A razão para a ocorrência dessa situação não é apenas uma questão de mercado, mas também de conjuntura, analisada no tópico "Dificuldades". 
A Lei Geral $^{13}$ classifica as empresas com faturamento anual de até $\mathrm{R} \$ 240.000,00$ como Microempresa (ME) e de R \$ 240.000,00 a R \$ 2.400.000,00 como Empresa de Pequeno Porte (EPP). A situação que se apresenta no município de Chapecó mostra que a atividade de fabricação de móveis sob medida é característica de microempresas (62\%) e empresas de pequeno porte (38\%). Já entre as que fabricam móveis em série nessa cidade, 50\% são classificadas como Empresa de Pequeno Porte. Se forem tomadas todas as empresas de Chapecó e somadas as classificadas como microempresas e empresas de pequeno porte, tem-se um total de $95 \%$ de empresas que poderiam, em tese, se beneficiar da Lei do Simples.

Das empresas de Coronel Freitas, embora sua estrutura física seja grande, pelo seu faturamento, $72 \%$ são classificadas como Empresa de Pequeno Porte. Esse aspecto corrobora a informação acima quanto à ociosidade apurada. Aqui cabe uma ressalva: as empresas que, para contornar os problemas gerados pela Lei Geral, trabalham com duas razões sociais, foram aqui consideradas como uma única empresa. Se classificarmos todas as empresas do polo sem nenhuma segmentação, pode-se concluir que a realidade desse polo moveleiro é as empresas serem preferencialmente microempresa e empresa de pequeno porte $(91 \%)$. Pode-se perceber ainda que apenas $9 \%$ das empresas não são classificadas como tal. No entanto, se a classificação fosse feita de acordo com a projeção de faturamento no cenário abordado acima, esse dado passaria para $22,8 \%$ das empresas.

\section{Dificuldades apontadas}

Apurou-se que, em Chapecó, as três principais dificuldades apontadas são: impostos, falta de mão-de-obra qualificada e legislação trabalhista, nessa ordem. Pela análise conjuntural realizada por muitos dos empresários ouvidos, essas são as razões do fechamento de tantas empresas na cidade. O aspecto da falta de mão-de-obra qualificada é tão importante que a própria AMOESC, em conjunto com o SEBRAE e o SENAI, criou a Escola Técnica Moveleira ${ }^{14}$, um local relativamente amplo que oferece cursos para os funcionários das empresas moveleiras no sentido de qualificar a mão-de-obra contratada. $\mathrm{O}$ curso já preparou três turmas, mas está encontrando dificuldades para a quarta por absoluta falta de interesse dos funcionários e até mesmo das empresas. Um empresário de móveis de categoria "alta classe" (sob medida) destoa dessa análise, afirmando que, para ter essa mão-de-obra qualificada, basta formá-la e pagar bem ${ }^{15}$ para mantê-la. Quanto aos impostos, na verdade parece haver apenas desinformação.

Analisando-se minuciosamente alguns itens específicos, chega-se às seguintes inferências: representam:

1) As empresas que apontaram "mão-de-obra" como a principal dificuldade de sua organização

- 34,5\% dos fabricantes de móveis sob medida que possuem 33,5\% do faturamento do segmento;

- $50 \%$ dos fabricantes de móveis seriados que possuem $88,3 \%$ do faturamento do segmento em Chapecó;

- 5,6\% das empresas de Coronel Freitas, o que corresponde a 5,6\% do faturamento destas.

Percebe-se que, efetivamente, o problema se localiza nas empresas seriadas de Chapecó. Esse mesmo problema é enfrentado pelas agroindústrias do município. Apenas uma empresa contatada afirma que no decorrer de 2007 permaneceu com aproximadamente 500 vagas abertas em sua linha de produção.

2) As empresas que apontaram "Impostos" como a principal dificuldade de sua organização representam:

- $31 \%$ dos fabricantes de móveis sob medida que possuem 32,4\% do faturamento do segmento;

- $20 \%$ dos fabricantes de móveis seriados que possuem apenas 1,8\% do faturamento do segmento em Chapecó;

- 38,9\% das empresas de Coronel Freitas, que possuem 36,1\% do faturamento destas.

Percebe-se que as pequenas empresas seriadas de Chapecó acham ser esse o maior problema. Para a mudança desse conceito, basta fornecer-lhes informação.

3) Apenas uma empresa de Coronel Freitas apontou "Legislação Trabalhista" como a principal dificuldade de sua organização. Esse item foi muito indicado como $2^{\mathrm{a}}$ ou $3^{\mathrm{a}}$ causa.

\footnotetext{
${ }^{13}$ Lei complementar 123/04 que institui o Estatuto Nacional da Microempresa e da Empresa de Pequeno Porte, também chamada de Lei do Simples.

${ }^{14}$ A Escola funciona em um pavilhão alugado, mas tem as principais máquinas, equipamentos e ferramentas utilizadas nas empresas. Um dos instrutores é, inclusive, um proprietário de empresa moveleira.

${ }^{15}$ Os marceneiros nessa empresa recebem em torno de R \$ 2.500,00 mensais. Essa remuneração inclui um salário fixo acrescido de participação nos projetos/produtos desenvolvidos.
} 
A preocupação com a legislação trabalhista reside na verdade nos custos dos encargos sociais. A alternativa buscada pelas empresas de móveis sob medida é a terceirização. Esse assunto, no entanto, não é totalmente tranquilo na interpretação de muitos juízes trabalhistas. Toda querela nesse sentido sempre representa um importante ônus para as microempresas.

O item que vem em quarto lugar em Chapecó é "capital de giro". A análise que se pode fazer desse aspecto está na falta de capacidade gerencial, visto que os controles administrativos, contábeis, de estoque, de contas a pagar e a receber são, em muitos casos, completamente inexistentes. Esta é, com raras exceções, a característica principal das empresas que fabricam móveis sob medida. Aliás, destas, as que estão se sobressaindo e alcançando lucratividade são aquelas que se profissionalizaram e buscaram nichos específicos de mercado, como, por exemplo, móveis para as classes A e B.

Ainda, nesta pesquisa, a questão permitia a manifestação além dos itens discriminados. Foram então citadas outras dificuldades pelos fabricantes de móveis sob medida: efeitos dos financiamentos, inadimplência, móveis em série, separação civil do sócio, brigas em família, falência no antigo endereço e agora a dificuldade de recomeçar em um novo endereço, ausência de crédito, inexistência de funcionários, a concorrência do "marceneiro de fim de semana", legislação para instalação (ambiental, municipal, etc.), locomoção e entrega, móveis modulados vendidos nas lojas a preços "de banana" e que acabaram com o mercado.

Por outro lado, os empresários de Chapecó que fabricam móveis em série apontam outras dificuldades (além das listadas): manutenção industrial, custos de matéria-prima e acessórios, espaço físico e restrições bancárias por problemas de cadastro.

Para as empresas de Coronel Freitas, a situação é bem diferente. Os impostos foram citados como o principal problema. Nesse sentido, a operacionalização do "Novo Super Simples" está onerando significativamente as empresas. A alternativa encontrada está sendo a abertura de mais uma empresa (razão social) para minimizar seus efeitos perversos e, dessa forma, gerir entre as duas razões sociais, de forma cuidadosa, os itens compras, faturamento, mão-de-obra, créditos tributários, etc. ${ }^{16}$. O mercado consumidor foi citado com bastante veemência. Nesse sentido, o confronto com a ociosidade de faturamento, apontada anteriormente, deixa bem clara a situação. Só nesse município poderia haver um faturamento maior que o atual em $\mathrm{R} \$ 31.745 .000,00$, ou seja, o atual faturamento poderia mais do que dobrar, caso o mercado absorvesse a produção da atual capacidade instalada. Na manifestação livre, houve diversas opiniões que revelaram aspectos bem intrínsecos. O câmbio ou a situação econômica do país foi citado sete vezes entre os dezoito empresários. Em seguida vieram: falta de educação dos proprietários - que pode ser interpretado como empáfia ou hostilidade mútua; concorrência indireta crédito fácil para veículos, com taxas menores que $1 \%$, ao passo que as lojas cobram acima de $3 \%$; falta de treinamento dos funcionários; localização geográfica.

O SEBRAE realiza, em nível nacional, uma pesquisa anual no intuito de identificar as principais dificuldades que as empresas enfrentam, bem como as principais causas do seu fechamento. O resultado dessa pesquisa mostra que, historicamente, as três principais causas são: políticas públicas e arcabouço legal, causas econômicas conjunturais e carga tributária elevada. Confrontando esses resultados com o estudo aqui realizado, pode-se depreender da situação como um todo que cada organização tem um conjunto de dificuldades intrínsecas, que exigem soluções bastante específicas para cada uma delas.

\section{Produtos e nível tecnológico}

A tecnologia na indústria de móveis em geral é tradicional e acessível a todas as empresas, tendo a possibilidade de atualização técnica por meio da aquisição de máquinas e equipamentos ofertados no mercado nacional e internacional. A aquisição de matérias-primas específicas não tem sido um diferencial de competitividade, visto que os mesmos fornecedores negociam com todas as empresas estudadas. Assim sendo, todas as empresas, em algum momento ou produto, utilizam MDF (medium-density fiberboard). A utilização dessa matéria-prima vem permitindo a introdução de máquinas e dispositivos eletrônicos e óticos para controlar a forma, o corte, a perfuração e o acabamento, permitindo assim uma evolução tecnológica importante, um controle e flexibilização dos processos cada vez maior, gerando uma

\footnotetext{
${ }^{16}$ A propaganda oficial afirma que a sistemática do Super Simples está gerando a abertura de muitas novas empresas. Em inúmeros casos, essta abertura de empresas é feita por empresas estabelecidas (como no caso de várias empresas pesquisadas) e tem o único objetivo de tentar diminuir o forte aumento da carga tributária gerado.
} 
diversificação de produtos e ganhos em escala. Por outro lado, a adoção dessas tecnologias gera uma menor demanda de mão-de-obra.

Analisando as indústrias pesquisadas como um todo, percebe-se que há um leque de produtos bastante diversificado. Enquanto as fábricas de móveis sob medida produzem qualquer móvel que tenha demanda - como não podia deixar de ser -, as fábricas de móveis seriados procuram se ajustar para produtos com alta demanda no mercado. O problema parece estar justamente na definição de seu core competition. Poucas empresas têm um portfólio pequeno e com grande produção. Chama muito a atenção a postura da estratégia concorrencial. Para a maioria, a maior preocupação está naquilo que o concorrente está produzindo e vendendo bem, para em seguida copiá-lo, fazendo pequenas modificações ou melhorias para também disponibilizar no mercado o mesmo produto.

Apenas uma fábrica está atualmente trabalhando para exportação. Todas as demais somente atendem o mercado nacional, especialmente os estados do sul e a cidade de São Paulo. A venda diretamente para as redes de varejo também permite eliminar o elo "atacadista" da cadeia. Segundo um dos empresários, está sendo organizada no Rio Grande do Sul uma entidade das redes de varejo, com o intuito de barganhar as compras de forma centralizada e eliminar de seu mercado fornecedor as fábricas que não se enquadrarem em suas especificações. Essa hipótese está sendo uma importante fonte de ansiedade, pois imagina-se que atuará fortemente na questão de preços.

Na tabela 4 estão discriminados os principais produtos com a respectiva classificação discutida.

Tabela 4. Discriminação da produção do polo moveleiro de Coronel Freitas - 2007.

Table 4. Production characterization of wood furniture in the pole of Coronel Freitas -2007.

\begin{tabular}{ll}
\hline Móveis sob medida & Projetos de arquitetos. \\
& Projetos de clientes. \\
& Desenhos/croquis de clientes/próprio dono. \\
& Quadro escolar. Mesas CPU. \\
& Qualquer móvel de acordo com o cliente. \\
& Projetos especiais de alta complexidade (em aço e madeira). \\
& Aberturas (portas e janelas). \\
& Urnas funerárias. \\
& Reformas \\
\hline Móveis em série & Móveis escolares e para escritórios (em aço e chapas de madeira). \\
& Jogos de sala. \\
& Balcões para banheiro. \\
& Móveis “alta classe”: sala, quarto, etc. \\
& Móveis em aço e madeira. \\
\hline Móveis em série & Cozinhas moduladas. (cinco empresas). \\
& Estofados e poltronas (duas empresas). \\
& Cozinhas e móveis tubulares. \\
& Balcões para banheiro. \\
& Mesas e cadeiras. \\
& Mesas, cadeiras e camas. \\
& Roupeiros com pintura em impressão. \\
& Móveis da "linha popular" com produtos específicos por região. \\
& Móveis para quartos (camas de eucalipto). \\
& Salas de jantar e mesas para cozinhas. \\
& Móveis para quartos (camas) de acordo com o pedido do \\
& importador. \\
\hline &
\end{tabular}

Fonte: Bieger (2008).

O mercado em que cada empresa atua determina a tecnologia empregada. Assim, fabricar aberturas (portas e janelas) na linha popular necessita apenas dos equipamentos básicos de marcenaria. Portanto, analisando o nível tecnológico das indústrias desse polo moveleiro, pode-se afirmar que vai do artesanal à mais moderna tecnologia, com linha totalmente automatizada e com pintura em impressão. Embora todos tenham, em tese, livre acesso aos melhores padrões tecnológicos, isso só se verifica em boa parte das indústrias seriadas. 
Um fato bem interessante neste momento está sendo a compra de equipamentos usados do polo moveleiro de São Bento do Sul e Rio Negrinho. Neste importante polo moveleiro, diversas fábricas já fecharam e outras estão fechando por estarem voltadas apenas para o mercado exportador, e o câmbio é alegado como sendo o responsável pela inviabilização daquele mercado. As máquinas ali adquiridas estão possibilitando um incremento considerável no aspecto tecnológico a um custo razoável.

\section{Concepção de novos produtos}

Conceber novos produtos parece ser a visão da empresa levada ao "chão de fábrica". É enxergar a empresa se projetando em horizontes de curto, médio e longo prazos, com novos produtos, novas relações mercadológicas, inovando e reinventando-se diante de cada novo desafio.

Salvo raras e elogiosas exceções, o polo não consegue uma atuação de vanguarda que o coloque na condição de ditar tendências de consumo ou, pelo menos, aproveitando as demandas dos grandes mercados, criar produtos com uma característica marcante desse polo, dessa região. Segundo a maioria dos empresários, não há graus de liberdade para se embutir nos custos das empresas esse tipo de dispêndio que fatalmente elevaria seu preço final, com consequentes problemas de comercialização. Prevalece a cópia de modelos inspirados em revistas, feiras ou produtos de concorrentes, com algumas modificações de acordo com a vontade do cliente ou representante, lançando um produto modificado ou adaptado como se fosse novo.

Um departamento de pesquisa e desenvolvimento de novos produtos é encontrado somente em algumas empresas de Chapecó. Percebe-se que são justamente as empresas que continuam ampliando sua participação no mercado e obtendo lucratividade dentro da expectativa de seus proprietários. Por outro lado, esse item é considerado um custo desnecessário para a maioria das empresas. Em Coronel Freitas, o item "Tendência de mercado" tem dois significados: sugestões/indicações dos vendedores ou o que o concorrente está vendendo. Esse processo poderia ser considerado de benchmarking, mas, nesse contexto, para algumas empresas, não há a intenção do aprendizado e da melhoria contínua, tão característicos nessa ferramenta organizacional. O objetivo subjacente é rapidamente ter um produto igual ou parecido para "ratear" uma demanda emergente.

\section{Resíduos}

Absolutamente todos os entrevistados declararam estar motivados e preocupados em planejar adequadamente sua produção com o objetivo de obter o máximo aproveitamento dos materiais, evitando desperdícios. Nesse mesmo sentido, eles afirmam ter uma permanente preocupação com o destino dos resíduos finais, produzidos ao longo da produção. Circulando pelas indústrias, percebe-se que essa não é bem a realidade. Especialmente nas fábricas sob medida e com menos tecnologia há resíduos e sujeira por toda a parte, tanto dentro como fora dos galpões. Algumas têm exaustores instalados, mas que não funcionam há muito tempo, a ponto de ter vegetação em volta dos depósitos externos, evidenciando que eles também não estão sendo usados. Em contraponto a essa situação, foram encontradas empresas exemplarmente limpas, com a correta separação dos resíduos e a adequada destinação dada a eles.

Há um padrão para o destino dado aos cavacos de madeira: lenha para fogões ou caldeiras na forma de venda ou doação. A maravalha é armazenada e vendida como "cama de aviário" aos avicultores da região. É um produto com bastante procura. O pó, restos/sobras de espuma, borracha, tecidos, metais e a borra de tinta são recolhidos pela CETRIC (Central de Tratamento de Resíduos Sólidos Industriais). Houve inclusive algumas manifestações de ceticismo com relação ao destino que essa empresa dá aos resíduos recolhidos, especialmente a borra de tinta. Em visita a essa empresa, verificou-se a sua seriedade e profissionalismo, bem como a permanente preocupação com o tratamento adequado dos resíduos industriais de toda a região.

\section{Mão-de-obra}

O polo moveleiro em pauta utiliza mão-de-obra com características diferentes em suas linhas de produção. Para as fábricas com produtos modulados/em série, a qualificação não é muito exigida, visto que o funcionário se especializa em um ou poucos aspectos/etapas da produção. Já para os móveis sob medida, esse problema é apontado pela maioria como crucial, com exceção de um empresário, que se mostra plenamente satisfeito com a qualificação de seus funcionários, que já o acompanham há onze 
anos. A receita apontada por ele é a qualificação e o treinamento dentro da própria empresa e a consequente melhoria na remuneração, para mantê-lo produzindo.

Nas visitas às linhas de produção, observou-se que, quanto menor a empresa, menos equipamentos de segurança os funcionários/operadores utilizam. Nestas não foi difícil encontrar o próprio dono ou algum funcionário com sinais de importantes mutilações provocadas por máquinas ou equipamentos.

Em termos de quantidade de funcionários, percebeu-se que a grande maioria $(90 \%)$ dessas unidades fabris tem menos de dez funcionários (média: 6,6 funcionários/empresa). A sazonalidade do serviço ou demanda de produtos não tem permitido uma maior contratação. A alternativa encontrada por alguns é a contratação temporária de tarefeiros, que são remunerados apenas pelo serviço executado, sem nenhum vínculo empregatício. É, na verdade, uma terceirização informal e uma maneira de fugir da legislação trabalhista. Por outro lado, aponta para a celebração de parcerias, que poderiam ser implementadas.

Em Chapecó, percebe-se que, das empresas que fabricam móveis em série, $20 \%$ têm um pequeno número de funcionários (menos do que 10). Essas empresas têm, em tese, tecnologia e produto para se transformarem em empresas com grande potencial produtivo. Um plano de negócios bem estruturado poderia alavancar o incremento de mais uma indústria de porte na região. Nesse mesmo município, 50\% das empresas analisadas possuem entre 20 e 40 funcionários. Nestas, porém, estão apenas $32 \%$ das vagas ociosas de Chapecó.

Quase todas as empresas de Coronel Freitas são consideradas empresas grandes no município. No entanto, a quantidade de funcionários varia significativamente. Enquanto tem-se $11 \%$ em cada estrato de "abaixo de 10" e "acima de 50", nos estratos de "11 a 20" e "31 a 40" são $28 \%$, e de $22 \%$ no estrato de "21 a 30" funcionários. Não há nenhuma empresa no estrato de "41 a 50" funcionários.

A figura 2 expressa todas as empresas do polo moveleiro em uma só figura com essa mesma classificação individualizada. Percebe-se que quase $70 \%$ das empresas do polo possuem até vinte funcionários. Por esse critério, pode-se concluir que o polo moveleiro de Coronel Freitas é constituído praticamente apenas por pequenas empresas.

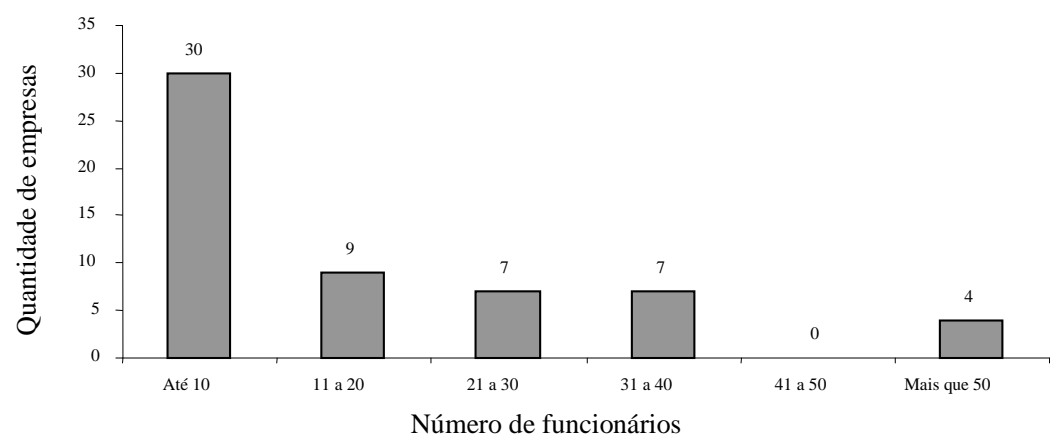

Figura 2. Classificação das empresas de móveis do polo moveleiro de Coronel Freitas quanto ao número de funcionários -2007.

Figure 2. Classification of the furniture companies of Coronel Freitas pole according to the number of Fonte: Bieger (2008). employees -2007.

Buscou-se também identificar o perfil da mão-de-obra que está trabalhando nas fábricas em termos de grau de instrução. Evidenciou-se a concentração da mão-de-obra com formação de ensino fundamental nas fábricas que produzem móveis em série. O total de pessoas que possuem apenas o ensino fundamental representa 55\% de toda a mão-de-obra empregada no setor. Já os funcionários que possuem 
ensino médio representam $30 \%$ desse total. Os alfabetizados ${ }^{17}$ representam $11 \%$, os com nível superior são $3 \%$ e os analfabetos são menos de $1 \%$.

Considerando a realidade econômica descrita pelo Ministério da Integração Nacional (MI) sobre a Mesorregião da Grande Fronteira do Oeste Catarinense, classificando-a como uma região em estagnação, buscou-se apurar a capacidade ociosa em termos de mão-de-obra. Os dados apontam uma ociosidade de 42,8\% somente na questão da mão-de-obra. A figura 3 mostra os empregos existentes, o potencial com a capacidade instalada e também a ociosidade das fábricas pesquisadas, considerando a estratificação por município e por segmento.

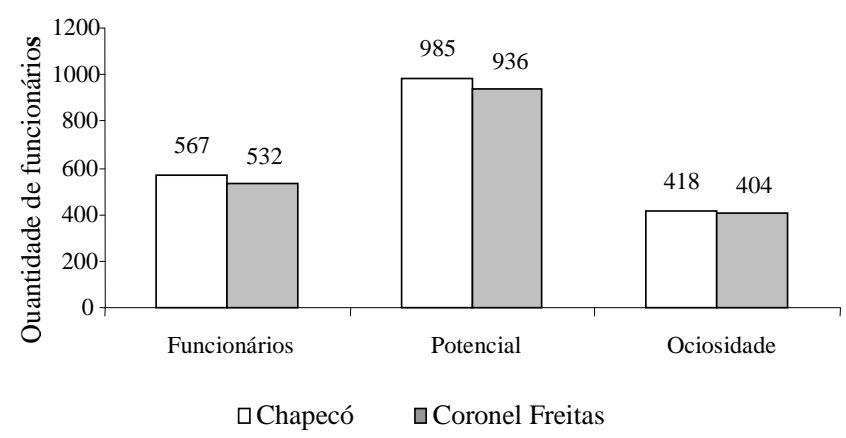

Figura 3. Mão-de-obra, potencial e ociosidade no polo moveleiro de Coronel Freitas por município 2007.

Figure 3. Labor force, potential and idleness in the furniture pole of Coronel Freitas by county -2007 . Fonte: Bieger (2008).

Percebe-se uma importante ociosidade nas indústrias. Números absolutos apontam para 822 vagas em aberto, sendo 418 em Chapecó e 404 em Coronel Freitas. Nesta cidade, $41 \%$ dessas vagas estão nas empresas que hoje possuem entre 20 e 40 funcionários, e $51 \%$ das vagas estão naquelas que têm até 20 funcionários. As empresas teriam todo o interesse em aumentar o seu efetivo, caso as dificuldades inerentes a cada uma fossem equacionadas.

\section{Mercado consumidor e suas relações}

As fábricas de móveis sob medida obviamente não vendem para o atacado. No entanto, $6 \%$ de seu faturamento destinam-se a lojas de varejo, o que representa um valor de $\mathrm{R} \$ 348.000,00 /$ ano. Para consumidor sem pedido são destinados apenas $\mathrm{R} \$ 40.000,00$ (menos de 1\%). Com reformas há um faturamento de $\mathrm{R} \$ 75.000,00(1,33 \%)$ e o restante $(\mathrm{R} \$ 5.191 .000,00)$ é o faturamento com a confecção de móveis por pedido - sob medida propriamente dito. O cliente é aguardado na fábrica ou escritório, pessoalmente ou por telefone, e, quando não há um projeto, alguém da fábrica, normalmente o próprio dono, se dirige ao local solicitado, efetua a medida, elabora um croqui ou projeto e passa a construir o móvel solicitado. Não há nem mesmo a formalização em algum documento dessa transação.

As fábricas de móveis modulados ou em série têm um mercado consumidor bem diversificado. Seu faturamento de R \$ 43.735.000,00 está discriminado na tabela 5. Percebe-se que mais de 70\% são destinados a lojas de varejo, normalmente redes de varejo.

Uma das fábricas de Chapecó abriu uma loja no centro da cidade no decorrer desta pesquisa. Inicialmente não havia essa pretensão, mas uma oportunidade de negócio (sala comercial) propiciou essa investida no varejo local. Para o lançamento dessa loja, foi feito um plano de marketing com uma estratégia que se revelou extremamente acertada. Segundo seu proprietário, a projeção mais otimista, em termos de venda, foi superada largamente.

\footnotetext{
${ }^{17}$ Alfabetizados - funcionários que não completaram o ensino fundamental, mas que sabem assinar o nome, ler pequenos textos e fazer algumas operações matemáticas básicas.
} 
Tabela 5. Destino da produção em reais (anual) das fábricas de móveis em série de Chapecó e Coronel Freitas - 2007.

Table 5. Production destination in $\mathrm{R} \$$ (annual) from the plants of serial furniture of Chapecó and Coronel Freitas - 2007.

\begin{tabular}{|c|c|c|c|c|c|c|c|c|c|c|c|c|}
\hline \multirow{3}{*}{$\begin{array}{l}\text { Discriminação } \\
\text { Município } \\
\text { Faturamento } \\
\text { (em R\$ 1.000) }\end{array}$} & \multicolumn{2}{|c|}{$\begin{array}{c}\text { Atacado } \\
(20,26 \%) \\
\end{array}$} & \multicolumn{2}{|c|}{$\begin{array}{c}\text { Lojas de varejo } \\
(71,88 \%)\end{array}$} & \multicolumn{2}{|c|}{$\begin{array}{c}\text { Varejo próprio } \\
(2,33 \%)\end{array}$} & \multicolumn{2}{|c|}{$\begin{array}{c}\text { Consumidor sem } \\
\text { pedido }(0,57 \%)\end{array}$} & \multicolumn{2}{|c|}{$\begin{array}{l}\text { Consumidor por } \\
\text { pedido }(0,02 \%)\end{array}$} & \multicolumn{2}{|c|}{$\begin{array}{c}\text { Exportação } \\
(4,94 \%)\end{array}$} \\
\hline & Chapecó & $\begin{array}{c}\text { Cel. } \\
\text { Freitas }\end{array}$ & Chapecó & $\begin{array}{l}\text { Cel. } \\
\text { Freitas }\end{array}$ & Chapecó & $\begin{array}{c}\text { Cel. } \\
\text { Freitas }\end{array}$ & Chapecó & $\begin{array}{c}\text { Cel. } \\
\text { Freitas }\end{array}$ & Chapecó & $\begin{array}{c}\text { Cel. } \\
\text { Freitas }\end{array}$ & Chapecó & $\begin{array}{c}\text { Cel. } \\
\text { Freitas }\end{array}$ \\
\hline & 5.900 & 2.960 & 9.690 & 21.745 & 1.020 & 0 & 250 & 0 & 10 & 0 & 0 & 2.160 \\
\hline Total & \multicolumn{2}{|c|}{8.860} & \multicolumn{2}{|c|}{31.435} & \multicolumn{2}{|c|}{1.020} & \multicolumn{2}{|c|}{250} & \multicolumn{2}{|c|}{10} & \multicolumn{2}{|c|}{2.160} \\
\hline
\end{tabular}

Fonte: Bieger (2008).

Nessa tabela, também se pode perceber que menos de $5 \%$ do faturamento é destinado à exportação, mostrando que um dos grandes objetivos da AMOESC - que é justamente estimular as vendas para esse mercado - não está sendo atingido pelas indústrias estabelecidas em Chapecó e Coronel Freitas. Confrontando com os valores apurados pelo grande Polo Moveleiro do Oeste, que faturou 18 milhões em 2006, os R \$2.160.000,00 exportados por Coronel Freitas representam 12\% daquele valor.

Em termos geográficos, além da exportação, a produção se destina aos três estados do Sul (Paraná, Santa Catarina e Rio Grande do Sul) mais São Paulo. Pelas informações obtidas, não foi possível apurar a participação de cada um.

\section{Preocupação com reflorestamento}

O conceito de reflorestamento aqui utilizado é o que tem sido empregado na legislação oficial, bem como o popularizado nas empresas do ramo, ou seja, é o plantio de essências florestais (nativas ou exóticas) com objetivos comerciais.

Entre todos os proprietários das empresas do polo moveleiro, apenas seis disseram que possuem reflorestamento e, assim mesmo, particular, não da empresa que, via de regra, tem mais sócios. O total apurado foi uma área de 34 ha de pinus e mais 30 ha de eucalipto. Haveria ainda uma intenção de reflorestar mais 50 ha por parte de um dos proprietários de uma das empresas.

Mesmo considerando um consumo mensal apurado de $640 \mathrm{~m}^{3}$ de eucalipto e mais $624 \mathrm{~m}^{3}$ de pinus, não há aparentemente nenhuma preocupação com a garantia do provimento dessa matéria-prima por parte dos empresários. Corroborando essa situação, tem-se uma oferta substancial com preço aceitável. Essa oferta é o resultado do trabalho de fomento desenvolvido pelas agroindústrias nas últimas três décadas. Esse incentivo das agroindústrias foi propiciado com o intuito de garantir o abastecimento de lenha para o aquecimento dos aviários dos agricultores a elas integrados, bem como a compra dos excedentes pelas próprias agroindústrias. Devidamente orientados, os avicultores não efetuaram cortes rasos em seus reflorestamentos, deixando as melhores árvores para a produção de toras. Essa produção de toras está atualmente abastecendo as serrarias, que vendem a madeira serrada para as indústrias moveleiras.

\section{Aspectos econômicos}

Avaliar o desempenho econômico de um setor tem-se revelado uma missão bastante complexa. As inter-relações comerciais, os interesses paralelos, os incentivos ou restrições de ordem oficial, as estruturas do macromercado existente, entre outras, são variáveis que direta ou indiretamente exercem poder e influenciam o desempenho e seu desenvolvimento. Apesar disso, algumas análises são pertinentes e possibilitam diversas avaliações, mesmo que parciais. Em função da total informalidade das empresas de móveis sob medida, não há nenhuma restrição quanto a "novos entrantes" nesse mercado, tampouco há restrições quanto à saída. Já para móveis em série, as principais restrições são os altos investimentos necessários, a definição do mix de produtos, a conquista de mercados e a situação econômica do momento.

Pelos dados levantados, percebe-se que apenas $8,77 \%$ das empresas faturam mais do que $\mathrm{R} \$$ 2.400.000,00/ano. Se forem tomadas apenas as informações das empresas que fabricam móveis em série, ter-se-ia um percentual de 64,29\% de empresas na faixa de $\mathrm{R} \$ 240.000,00$ a $\mathrm{R} \$ 2.400 .000,00$ de faturamento anual. Por outro lado, se forem consideradas todas as empresas do polo, serão $91,23 \%$ de empresas com faturamento menor que $\mathrm{R} \$ 2.400 .000,00 /$ ano. Portanto, a característica dominante do polo é ter empresas de pequeno porte ou microempresas. 


\section{Produtividade}

Diversos conceitos podem ser utilizados para produtividade. Aqui foram feitas algumas comparações, considerando-se as variáveis faturamento e mão-de-obra. Ao se confrontarem essas variáveis, percebe-se que as empresas com faturamento entre $\mathrm{R} \$ 240.000,00$ e $\mathrm{R} \$ 2.400 .000,00$ (classificadas como EPP) têm um resultado bastante semelhante, produzindo, respectivamente, R\$ $42.178,22$ e $\mathrm{R} \$ 45.462,78$ por funcionário/ano.

Abrindo-se as informações das empresas de móveis seriados, confrontando as localizadas em Chapecó e Coronel Freitas, com o objetivo de verificar se os aspectos geográficos têm alguma influência no desempenho, os resultados indicam que nas microempresas (ME) e empresas de pequeno porte (EPP) os valores são similares. Já entre aquelas que faturam acima de $\mathrm{R} \$ 2.400 .000,00$, as empresas de Coronel Freitas mostram-se bem mais eficientes ( $\mathrm{R} \$ 82.000,00 /$ ano contra $\mathrm{R} \$ 56.422,02 /$ ano das de Chapecó). Como essa situação parece não condizer com a realidade verificada nas visitas in loco, buscou-se uma explicação para essa discrepância. Analisando os dados e o perfil das empresas classificadas nesse segmento, verificouse que as empresas de Chapecó classificadas neste estrato fabricam um mix de produtos destinados às classes A e B e, portanto, têm uma demanda muito maior em mão-de-obra em suas linhas de produção. Comparando as empresas com produtos similares, os resultados são bastante semelhantes.

\section{Estrutura e concentração do mercado}

Em termos de estrutura e concentração de mercado, faz-se aqui a análise pela TCM (Taxa de Concentração do Mercado) e pelo IHH (Índice de Herfindahl-Hirschman).

A tabela 6 apresenta a TCM para as diversas classificações estudadas, considerando o faturamento dos quatro maiores produtores em cada segmento. Percebe-se que, por esse critério, haveria forte concentração se fossem considerados como um mercado apenas os produtores de móveis seriados em Chapecó. Esse resultado é enganoso, visto que apenas 10 empresas estão incluídas nesse segmento. $\mathrm{Se}$, no entanto, for analisado o mercado exarado do polo moveleiro estudado, tem-se uma concentração relativamente baixa - concorrencial -, assim como nas demais classificações abordadas.

Tabela 6. Taxa de concentração do mercado (TCM) do polo moveleiro de Coronel Freitas - 2007, considerando os 4 maiores produtores de cada segmento.

Table 6. Market concentration rate (TCM) of the furniture pole of Coronel Freitas - 2007, considering the 4 major producers of each segment.

\begin{tabular}{lcccc}
\hline $\begin{array}{l}\text { Móveis sob medida } \\
\text { (Chapecó) }\end{array}$ & $\begin{array}{c}\text { Móveis seriados } \\
\text { (Chapecó) }\end{array}$ & $\begin{array}{c}\text { Móveis seriados } \\
\text { (Coronel Freitas) }\end{array}$ & $\begin{array}{c}\text { Móveis seriados } \\
\text { (Chapecó e Cel. Freitas) }\end{array}$ & $\begin{array}{c}\text { Polo } \\
\text { moveleiro }\end{array}$ \\
\hline $35,73 \%$ & $85,95 \%$ & $39,46 \%$ & $38,18 \%$ & $33,81 \%$ \\
\hline
\end{tabular}

Fonte: Bieger (2008).

O Índice de Herfindahl-Hirschman (IHH) é um índice que eleva ao quadrado o MS (Market Share), com o intuito de elevar o peso das maiores empresas dentre do mercado analisado. A tabela 7 apresenta um resumo dos valores dos Índices de Herfindahl-Hirschman (IHH) totalizados em cada segmento. Em cada um deles, tem-se valores inferiores a 1.800, o que caracterizaria um mercado competitivo. Seria muito importante efetuar estudos no sentido de se construir séries históricas desses valores, para avaliar a tendência da concentração do mercado e, paralelamente, estudar os fatores que determinam essa tendência.

Tabela 7. Índice de Herfindahl-Hirschman do polo moveleiro de Coronel Freitas - 2007.

Table 7. Herfindahl-Hirschman Index of the furniture pole of Coronel Freitas - 2007.

\begin{tabular}{lc}
\hline Segmento & IHH \\
\hline Móveis sob medida & 600,33 \\
Móveis em série & 647,47 \\
Todas as empresas & 515,58 \\
\hline
\end{tabular}

Fonte: Bieger (2008).

Aplicando-se os conceitos de Caves (1982) para a situação pesquisada e utilizando-se a variável "faturamento", são apresentados, na tabela 8, os percentuais dessa variável em cada segmento do polo moveleiro. 
Tabela 8. Percentuais de faturamento no polo moveleiro de Coronel Freitas - 2007.

Table 8. Invoicing Percentage of the furniture pole of Coronel Freitas -2007.

\begin{tabular}{lcccc}
\hline Segmento & 4 maiores & 8 maiores & $\mathbf{2 0}$ maiores & a maior \\
\hline Móveis sob medida & $35,73 \%$ & $60,84 \%$ & $94,09 \%$ & $9,55 \%$ \\
Móveis em série & $38,18 \%$ & $59,73 \%$ & $95,91 \%$ & $13,72 \%$ \\
Todas as empresas do polo & $33,81 \%$ & $52,90 \%$ & $84,93 \%$ & $12,15 \%$
\end{tabular}

Fonte: Bieger (2008).

Percebe-se pela tabela que, independente do segmento, tem-se um Oligopólio tipo I, pois as 8 maiores empresas faturam mais do que $50 \%$ do faturamento total, as 20 maiores contribuem com mais de $75 \%$ do total e, ainda, nenhuma firma sozinha fatura mais do que $10-15 \%$.

Os resultados dos três critérios analisados estão na tabela 9.

Tabela 9. Classificação da estrutura de mercado do polo moveleiro de Coronel Freitas de acordo com os critérios de TCM, IHH e Caves - 2007.

Table 9. Market Structure Classification of the furniture pole of Colonel Freitas in accordance with the criteria of TCM, IHH and Caves - 2007.

\begin{tabular}{llll}
\hline Segmento & \multicolumn{1}{c}{ TCM } & IHH & Caves \\
\hline Móveis sob medida & Mercado concorrencial & Mercado de alta competição & Oligopólio tipo I \\
Móveis em série & Mercado concorrencial & Mercado de alta competição & Oligopólio tipo I \\
Todas as empresas do polo & Mercado concorrencial & Mercado de alta competição & Oligopólio tipo I \\
\hline
\end{tabular}

Fonte: Bieger (2008).

Percebe-se que, pelo critério de Caves, tem-se uma classificação que difere das demais. Essa contradição deve ser analisada considerando algumas características peculiares desse mercado. Em primeiro lugar, pela variável analisada (faturamento) não ser a recomendada por Caves, que sugere a de produção. Porém, pela diferenciação dos produtos, isso não é possível. Da mesma maneira, têm-se pequenas empresas com produção relativamente pequena, mas com alto faturamento, e que atuam em nichos específicos, como, por exemplo, o de móveis de alta classe. Nesse sentido, o critério de Caves (1982), tal como aplicado na população estudada, pode equivocadamente induzir a uma conclusão precipitada, principalmente porque não capta as nuanças da diferenciação de produtos e dos níveis de produção. Por outro lado, os critérios TCM e IHH, ao considerarem os mercados como competitivos, podem ofuscar algumas particularidades de comportamento monopolístico, como a criação de nichos, ou até mesmo de comportamento oligopolístico, em que decisões das maiores empresas afetam as demais.

O mercado analisado é bastante dinâmico. Por essa razão, os resultados aqui apresentados dão uma ideia geral de sua estrutura. Observou-se no decorrer da pesquisa que as empresas de móveis de Chapecó, tanto de seriados como de móveis sob medida, têm estratégias de ação bastante peculiares. As líderes em faturamento, por exemplo, agem monopolisticamente, criando e desenvolvendo seus produtos e estabelecendo os preços segundo critérios próprios, valorizando estilo, design e bom gosto. Atuam em nichos de mercado específicos e têm obtido alta lucratividade.

Já as empresas de Coronel Freitas parecem atuar eventualmente como em oligopólio. A característica que diferencia o oligopólio é que ele é um mercado em que o número de empresas é suficientemente pequeno para que as ações de uma empresa individual - envolvendo quantidade, qualidade, lançamentos, preços e condições de pagamento - exerçam influência perceptível em todo o setor, no caso as empresas daquele município. Portanto, a interdependência é perceptível entre as empresas que têm consciência de que suas decisões poderão influenciar o mercado.

\section{Discussão e sugestões de Políticas}

A pesquisa mostrou que o fornecimento de madeira ainda não é um gargalo à produção. $\mathrm{O}$ mercado local foi o maior demandante para os móveis sob medida. Para os móveis seriados, os mercados local, regional, dos três estados do Sul (especialmente as capitais) e da cidade de São Paulo foram os principais compradores. Observou-se apenas uma empresa exportadora, sendo seu principal produto camas de eucalipto para os Estados Unidos. 
Em termos de dificuldades organizacionais, as empresas apontaram os itens impostos, legislação trabalhista e mão-de-obra qualificada como as maiores dificuldades de sua atividade. Considerando que quem respondeu ainda está na atividade, parece não serem essas as causas de mortalidade nessa região. Mesmo assim parece que está havendo um problema generalizado de falta de informação e de real quantificação da carga tributária, visto que este percentual oscila em torno de 5\%.

No tocante à falta de mão-de-obra qualificada, espera-se que o trabalho desenvolvido pela Escola Moveleira comece a apresentar resultados no médio prazo. Quanto à legislação trabalhista, estudos desenvolvidos por especialistas locais apontam para $63,4 \%$ a incidência sobre a folha de pagamento, estimulando a informalidade.

Todas as empresas do polo moveleiro são empresas familiares, sendo seus proprietários responsáveis pela gestão das atividades. Quanto ao grau de instrução dos funcionários, este é significativamente baixo, sendo que $54,96 \%$ possuem apenas o ensino fundamental e $30,3 \%$ possuem o ensino médio. Com nível superior são apenas 3,37\%. Percebe-se, por esses dados, que ainda há um longo caminho a se percorrer no sentido da melhoria educacional da população.

Verificou-se que as empresas fabricantes de móveis seriados apresentam em média 32,4 empregados, que geram um faturamento médio de $\mathrm{R} \$ 1.561 .965,29$.

Observou-se que a maioria dos fabricantes de móveis sob medida apresenta em comum a completa desorganização de suas fábricas, de seus controles de produção, custos, caixa e clientes. Portanto, para esse grupo notou-se que a mudança no modelo de gestão torna-se prioritária. Aqueles que se profissionalizaram encontraram nichos de mercado (móveis de alta classe, por exemplo, estão operando com lucratividade). Para as demais empresas, resta a profissionalização como caminho de sobrevivência, apesar das resistências às mudanças. A autopercepção da incapacidade gerencial é baixa, e talvez seja esta a razão das muitas dificuldades e insucessos.

Em geral, o mercado apresentou-se como imperfeitamente competitivo, mas com nuanças na diferenciação de produtos e na busca de nichos de mercado que lembram características de concentração. O segmento de móveis seriados em Coronel Freitas é um caso típico.

A competitividade entre as empresas mostrou-se como fator inibidor da melhoria da lucratividade, como alegação de muitas delas. Em contrapartida, verificou-se uma necessidade premente da busca do associativismo para soluções coletivas e não individuais, como foi a manifestação de alguns. A própria razão de ser de uma associação não foi adequadamente entendida por outros.

Observa-se a ausência de foco na busca da profissionalização e da qualificação das unidades produtivas de móveis sob medida. Notou-se que as empresas por si só não conseguirão atingir seu intento, pela absoluta falta de condições financeiras, de relacionamento entre si (muitos nem se conhecem), de aspectos culturais (desconfiança da competição), organizacionais (gestão do negócio), além de outros. Esse trabalho deveria ser implementado prioritariamente em Chapecó, visto que em Coronel Freitas as ações do SEBRAE já transformaram as pequenas marcenarias em fábricas de móveis modulados/seriados que hoje têm outros problemas específicos, de diferentes naturezas.

Em termos de políticas que viabilizem a sustentabilidade econômica e social da atividade moveleira na região estudada, no longo prazo, destacam-se pontos que parecem ser adequados à situação estudada. Nesse sentido, algumas políticas poderiam ser implementadas são sistematizadas na tabela 10 .

\section{CONCLUSÕES}

Pelo censo realizado, foram encontradas em Chapecó vinte e nove unidades de produção fabricando móveis sob medida e dez fabricando móveis seriados, num total de trinta e nove em atividade no município. Já em Coronel Freitas, foram dezoito empresas, todas fabricando móveis em série. O cenário encontrado indicou haver uma forte tendência de diminuição do total das empresas.

Entre os fabricantes de móveis seriados há nítidas diferenças nas empresas localizadas nos municípios de Chapecó e de Coronel Freitas. Portanto, apresentam dificuldades, ansiedades e perspectivas também diferentes entre si. Em comum existe a necessidade urgente da aprendizagem (gestão, custos e qualidade), bem como uma mudança cultural importante no sentido do associativismo e na busca de soluções comuns, visto que a concorrência aparentemente predatória está alijando muitos fabricantes do mercado. 
A solução preconizada é no sentido de que localmente as empresas poderiam ser mais eficientes de forma coletiva em função da interação (cooperação e colaboração formal e informal) e da transformação do caráter de concorrência, competitividade e rivalidade local, evoluindo para uma competição com cooperação. Em suma, o polo moveleiro de Coronel Freitas (que abrange os municípios de Chapecó e Coronel Freitas) tem perspectivas de sustentabilidade que exige a busca do associativismo para soluções coletivas. envolvidos.

Essas soluções passam necessariamente pela conjugação de esforços de todos os atores

Tabela 10. Sistematização das políticas sugeridas para o polo moveleiro de Coronel Freitas.

Table 10. Suggested policies for the furniture pole of Coronel Freitas.

\begin{tabular}{|c|c|c|}
\hline Órgão/entidade & Política & Ações \\
\hline $\begin{array}{l}\text { Governos } \\
\text { municipais }\end{array}$ & $\begin{array}{l}\text { Estímulo à formalidade e ao } \\
\text { relacionamento entre as } \\
\text { empresas }\end{array}$ & $\begin{array}{l}\text { Prover a logística na criação de associações e de parcerias; envolver grupos } \\
\text { de PMEs e suas associações na formulação de estratégias de } \\
\text { desenvolvimento local; estabelecer uma política de aquisições públicas } \\
\text { dirigidas às PMEs locais e dar apoio logístico e de infraestrutura. }\end{array}$ \\
\hline $\begin{array}{l}\text { Associações } \\
\text { empresariais }\end{array}$ & $\begin{array}{l}\text { Estímulo à troca de } \\
\text { informações entre as } \\
\text { empresas }\end{array}$ & $\begin{array}{l}\text { Estabelecer grupos setoriais e temáticos de trabalho, coordenados e } \\
\text { moderados por associações profissionais; implantar bolsa de } \\
\text { subcontratações e/ou terceirizações. }\end{array}$ \\
\hline $\begin{array}{l}\text { Universidade, } \\
\text { instituições de } \\
\text { pesquisa e } \\
\text { treinamento }\end{array}$ & $\begin{array}{l}\text { Apoio direto às PMEs em } \\
\text { educação e tecnologia }\end{array}$ & $\begin{array}{l}\text { Viabilizar cursos de treinamento específicos para gestores de PMEs - } \\
\text { gestão, custos, qualidade, padronização, etc.; efetuar pesquisas de } \\
\text { produtos, de mercado, de configurações associativas, de apoio logístico, de } \\
\text { padronização, de qualidade, de certificação, etc.; estabelecer meios de } \\
\text { disseminação de informações tecnológicas e difundir o empreendedorismo. }\end{array}$ \\
\hline $\begin{array}{l}\text { Médias e grandes } \\
\text { empresas }\end{array}$ & $\begin{array}{l}\text { Desenvolvimento de } \\
\text { fornecedores }\end{array}$ & $\begin{array}{l}\text { Prestar assistência individual aos fornecedores; estabelecer fóruns de } \\
\text { discus-são e tomada de decisões sobre padrões de compra, venda, estoques } \\
\text { e entre-gas; estabelecer parcerias de acordo com as especificidades; } \\
\text { viabilizar uma central de compras. }\end{array}$ \\
\hline \multirow[t]{2}{*}{ Governo estadual } & $\begin{array}{l}\text { Estímulo ao relaciona-mento } \\
\text { entre empresas } \\
\text { Apoio tecnológico às PMEs }\end{array}$ & $\begin{array}{l}\text { Estabelecer política de aquisições públicas dirigidas para grupos ou } \\
\text { associações de PMEs locais e regionais. } \\
\text { Viabilizar centros de demonstração tecnológica; viabilizar serviços de } \\
\text { extensão; garantir e estabelecer linhas de financiamento das pesquisas; } \\
\text { prover apoio logístico; estabelecer fóruns de debate, feiras comerciais, etc. }\end{array}$ \\
\hline & $\begin{array}{l}\text { Apoio financeiro direto às } \\
\text { PMEs }\end{array}$ & $\begin{array}{l}\text { Viabilizar garantias de créditos para empresas com estratégias e projetos } \\
\text { formulados voltados ao desenvolvimento regional; estabelecer subsídios às } \\
\text { iniciativas de criação de redes para cobertura de custos transacionais. }\end{array}$ \\
\hline \multirow[t]{4}{*}{ Governo federal } & $\begin{array}{l}\text { Estímulo ao relaciona-mento } \\
\text { entre empresas }\end{array}$ & $\begin{array}{l}\text { Viabilizar a redução do custo Brasil: mudança dos impostos e da legislação } \\
\text { de forma a desestimular a informalidade; garantir procedimentos } \\
\text { transparentes e eficientes na administração pública e no comércio exterior. }\end{array}$ \\
\hline & $\begin{array}{l}\text { Apoio tecnológico direto às } \\
\text { PMEs }\end{array}$ & $\begin{array}{l}\text { Estabelecer linhas de financiamento para a descentralização de atividades } \\
\text { em base competitiva. }\end{array}$ \\
\hline & $\begin{array}{l}\text { Apoio direto às exportações } \\
\text { das PMEs }\end{array}$ & $\begin{array}{l}\text { Prover agências de promoção de exportações; estabelecer/disponibilizar } \\
\text { linhas de financiamento e seguro de exportações; equacionar a } \\
\text { desburocratização. }\end{array}$ \\
\hline & $\begin{array}{l}\text { Apoio financeiro direto às } \\
\text { PMEs }\end{array}$ & $\begin{array}{l}\text { Estabelecer linhas de financiamento da descentralização de atividades com } \\
\text { base competitiva; estabelecer/disponibilizar linhas de crédito para } \\
\text { atualização e inovação tecnológica; estabelecer/disponibilizar linhas de } \\
\text { financiamento para intercâmbios tecnológicos. }\end{array}$ \\
\hline
\end{tabular}

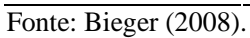

\section{REFERÊNCIAS}

BARBOSA, F. de H. Microeconomia: teoria, modelos econométricos e aplicações à economia brasileira. Rio de Janeiro: IPEA/INPES, 1985.

BIEGER, B. N. Caracterização e perspectivas do Pólo Moveleiro de Coronel Freitas-SC. 2008. 140f. Tese (Doutorado em Engenharia Florestal) - Universidade Federal do Paraná, Curitiba, 2008.

BNDES - BANCO NACIONAL DE DESENVOLVIMENTO ECONÔMICO E SOCIAL Disponível em: <http://www.bndes.gov.br/conhecimento/bnset/set2503.pdf >. Acesso em: 07/11/2007.

BOFF, H. P. Modelos de concorrência em Oligopólio. In: KUPFER, D.(Org.) Economia industrial: fundamentos teóricos e práticas no Brasil. Rio de Janeiro: Campos, 2002. 
CASSIOLATO, J. Interação, aprendizado e cooperação tecnológica. In: Séries Contribuições - Red Iberoamericana de indicadores de Ciencia y Tecnologia - RICYT, Agosto - 2004. Disponível em: <http://www.ricyt.org/interior/subredes\%5Cinnova\%5Cdocs/Cassiolato.pdf>. Acesso em: 31/10/2007.

CASTRO, A. M. G. de ; COBBE, R. V.; GOEDERT, W. J. Prospecção de demandas tecnológicas: manual metodológico para o SNPA. Brasília: Embrapa, 1995.

CASTRO, A. M. G.; LIMA, S. M. V.; HOEFLICH, V. A. Cadeias produtivas. Curitiba: TECPAR. 2002. Apostila.

CASTRO, A. M. G.; LIMA, S. M. V.; GOEDERT, W. J.; FREITAS FILHO, A. de; VASCONCELOS, J. R. P. (Ed.). Cadeias produtivas e sistemas naturais: prospecção tecnológica. Brasília: SPI/Embrapa, 1998. $564 \mathrm{p}$.

CAVES, R. E. American industry, structure, conduct and performance. Englewood Cliffs: Prentice Hall, 1982.

FAO. Forestry Department. Global planted forests thematic study - Results and analysis. December, 2006. Disponível em: https://www.fao.org.br/. Acesso em 01/05/2008.

GARRIDO, V.; GUERÓN, A. L. Requisitos ambientais, acesso a mercados e competitividade na indústria de madeira e móveis do Brasil. Disponível em: 〈http://www.inmetro.gov.br〉. Acesso em: 10/12/2004.

IBGE. Disponível em: <http://www.ibge.gov.br/>. Acesso em: 15/04/ 2006.

MENDES, J. B. Incentivos e mecanismos financeiros para o manejo florestal sustentável na Região Sul do Brasil. Relatório da FAO - Food And Agriculture Organization of the United Nation: Curitiba, 2004.

MOVERGS. Disponível em: <http://www.movergs.com.br/>. Acesso em: 18/12/2004; 21/01/2005.

PORTER, M. Competição: estratégias competitivas essenciais. 2.ed. Rio de Janeiro: Campus, 1999.

PORTER, M. Estratégia competitiva. Técnicas para análise de indústrias e da concorrência. 3.ed. Rio de Janeiro: Campus, 1986.

PORTER, M. Vantagem competitiva: criando e sustentando um desenvolvimento superior. Rio de Janeiro: Campus, 1989.

ROCHA, F.; BUENO, S.; PIRES, L. N. Dinâmica da concentração de mercado na Indústria Brasileira, 1996-2003. Disponível em: <http://www.ie.ufrj.br/datacenterie/pdfs/seminarios/pesquisa/texto1109.pdf>. Acesso em: 10/11/2007.

SANTOS, A. M. M.; GUARNERI, L. S. Características gerais do apoio a arranjos produtivos locais. BNDES Setorial, Rio de Janeiro, n. 12, p. 195-204, set. 2000.

SANTOS, M. A. S. Estrutura de mercado e desempenho exportador das empresas de artefatos de madeira do Estado do Pará. BASA/Biblioteca Virtual, 2003. Disponível em: <http://www.basa.com.br/bancoamazonia2/includes/institucional/arquivos/biblioteca/artigos/economiareg ional/EstruturadeMercado.pdf>. Acesso em: 10/11/2007.

SEBRAE, Sobrevivência e mortalidade das MPE. Fatores condicionantes, 2007. Disponível em: <http://www2.rn.SEBRAE.com.br/modules/news/article.php?storyid=168>. Acesso em: 09/10/2007.

SECEX / MDIC. Listagem de APL's prioritários no Brasil. Disponível em: 〈http://www.desenvolvimento.gov.br/portalmdic/arquivos/dwnl_1197310742.pdf>. Acesso em: 03/01/2008.

TESTA, V. M.; NADAL, R. de; MIOR, L. C.; BALDISSERA, I. T.; CORTINA, N. O desenvolvimento sustentável do Oeste Catarinense (Proposta para discussão). Florianópolis: EPAGRI. 1996

TORESAN, L. Desempenho e competitividade do setor florestal brasileiro e catarinense. Disponível em: <http://www.icepa.gov.br>. Acesso em: 15/11/2004. 